\title{
KUALITAS PELAYANAN STASIUN PENGISIAN BAHAN BAKAR UMUM PANRENG KECAMATAN BARANTI KABUPATEN SIDENRENG RAPPANG
}

\author{
1)Karmila Yusuf, ${ }^{2)}$ Kamaruddin Sellang, ${ }^{3)}$ Hariyanti Hamid \\ Fakultas IImu Sosial dan IImu Politik, Universitas Muhammadiyah Sidenreng Rappang \\ karmilayusuf43162070.1b@gmail.com
}

\begin{abstract}
Abstrak
Penelitian ini bertujuan untuk mengetahui kualitaspelayanan berpengaruh terhadap kepuasan pelanggan pada SPBU Panreng Kecamatan Baranti Kabupaten Sidenreng Rappang dan untuk mengetahui faktor apa yang paling tinggi pengaruhnya diantara kualitas pelayanan yang meliputi bukti fisik,kehandalan,jaminan, daya tanggap,dan empati terhadap kepuasanpelanggan di SPBU Panreng Kecamatan Baranti Kabupaten Sidenreng Rappang.Pendekatan metodepenelitian yang digunakan dalam penelitian ini adalah pendekatan deskriptif kuantitatif.Populasi dalam penelitian ini adalah pelanggan yang membeli bahan bakar minyak di SPBU Panreng yang diperkirakan dalam sehari ada 250 orang pembeli. Tekhnik sampel yangdigunakan yaitu Random Sampling dengan menggunakan rumus Slovin sehingga menghasilkan 71 sampel. Tekhnik pengumpulan data dilakukan dalam penelitian ini adalah observasi, kuesioner, dokumentasi, dan studi kepustakaan. Datayang terkumpul kemudian diolah dan dianalisis dengan menggunakan tekhnik analisis deskriptif kuantitatif dengan bantuan statistik deskriptif dengan menggunakan SPSS 21.0 dan Skala Likert. Dari hasil penelitian dan pembahasan nilai keseluruhan menunjukkan bahwa kualitas pelayanan berpengaruh terhadap kepuasan pelanggan, dinyatakan berpengaruh/signifikan dengan persentase sebesar 55,1\% yang diperoleh dari koefisien korelasi pada tabel model summary. Faktor kualitas pelayanan yang paling tinggi pengaruhnya adalah faktor indikator daya tanggap dengan persentase sebesar $74 \%$ yang diperoleh dari hasil akumulasi kuesioner.
\end{abstract}

Kata Kunci : Kualitas Pelayanan

\begin{abstract}
This study aims to determine the quality of service affect customer satisfaction at Panreng SPBU District Baranti Sidenreng Rappang District and to find out which of the quality of services which include physical evidence, reliability, assurance, responsiveness, and empathy that have a dominant influence on customer satisfaction at Panreng SPBU Baranti District, Sidenreng Rappang Regency. The approach of the research method used in this research is a quantitative descriptive approach. The population in this study is customers who buy fuel oil at Panreng gas station, which is estimated that there are 250 buyers a day. The sample technique used is Random Sampling using the Slovin formula to produce 71 samples. Data collection techniques carried out in this study were observation, questionnaires, documentation, and literature study. The collected data is then processed and analyzed using quantitative descriptive analysis techniques with the help of descriptive statistics using SPSS 21.0 and Likert Scale. From the results of the study and discussion of the overall value shows that: (1) the quality of service affects customer satisfaction, declared significant / significant with a percentage of $55.1 \%$ obtained from the correlation coefficient in the model summary table. (2) the service quality factor which has the highest influence is the responsiveness indicator factor with a percentage of $74 \%$ obtained from the results of the questionnaire accumulation.
\end{abstract}

Keywords: Service Quality

PRAJA | Volume 7 | Nomor 2 | Edisi Juni 2019 


\section{A. PENDAHULUAN}

Pembukaan Undang-Undang Dasar Negara Republik Indonesia 1945 alenia 4 menyatakan bahwa tujuan nasional, yaitu melindungi segenap bangsa Indonesia dan seluruh tumpah darah Indonesia, memajukan kesejahteraan umum, mencerdaskan kehidupan bangsa dan melaksanakan ketertiban dunia yang berdasarkan kemerdekaan, perdamaian abadi dan keadilan sosial.(Sellang, 2019) Dalam alinea tersebut terdapat pelayanan publik yang sangat menentukan tujuan nasional.

Upaya memenuhi kepuasan pelanggan, perusahaan memang di tuntut kejeliannya untuk memenuhi pergeseran kebutuhan dan keinginan pelanggan yang hampir setiap saat berubah. Pelanggan bisa mengalami salah satu dari tiga tingkat kepuasan umum yaitu kalau kinerja di bawah harapan, pelanggan akan merasa kecewa tetapi kinerja sesuai dengan harapan pelanggan akan merasa puas dan bila kineja bisa melebihi harapan maka harapan akan merasa sangat puas senang atau gembira (Philip Kotler, 1997). Jadi kepuasan pelanggan sangatlah berpengaruh bagi kesuksesan perusahaan. (Sunyoto, 2012). Proses perubahan yang terjadi dilingkungan SPBU baik internal maupun eksternal saat ini cukup pesat, terutama perubahan permintaan masyarakat akan kualitas pelayanan pengisian bahan bakar baik bensin, solar, pertalite, maupun pertamax. Oleh karena itu manajemen SPBU harus membuka diri untuk menerima perubahan ataupun pergeseran yang menyangkut sudut pandang (paradigma), perkembangan strategi, perkembangan struktur dan peningkatan kompetisi. (Edyansyah, 2016).

Penggunaan bahan bakar diperlukan untuk kebutuhan sehari-hari seperti transportasi pada umumnya. Transportasi di Indonesia sudah sangat berkembang seperti transportasi darat, laut dan udara.Transportasi darat saat ini sudah banyak dikembangkan seperti kendaraan roda dua atau sepeda motor, roda empat atau mobil, bus, truk dan lain-lain. Akibat dari haltersebut maka dampaknya terhadap kebutuhanbahanbakar semakin meningkat. Perusahaan yang memproduksi serta menyediakan bahan bakar untuk kebutuhan di Indonesia adalah Pertamina.(Pratiwi, n.d.)
Sistem eksternal perubahan permintaan masyarakat akan kualitas pelayanan pengisian bahan bakar baik bensin, solar, pertalite, maupun pertamax. Oleh karena itu manajemen SPBU harus membuka diri untuk menerima perubahan ataupun pergeseran yang menyangkut sudut pandang (paradigma), perkembangan strategi, perkembangan struktur dan peningkatan kompetisi. (Edyansyah, 2016), Karena SPBU tersebut memiliki banyak kekurangan seperti, pengendara roda dua dan roda empat masih memiliki jalur yang sama sehingga menyebabkan antrian dan pelanggan menunggu terlalu lama, tidak adanya sapaan/senyuman karyawan untuk konsumen saat pengisian bahan bakar dan ucapan terimakasih saat selesai pengisian bahan bakar, tidak terpakainya mhusollah, tidak tersedianya mesin pompa ban dan air radiator bagi konsumen yang memiliki masalah pada ban kendaraannya, tidak adanya Atm center bagi pengemudi yang kekurangan uang, dan tidak tersedianya tempat peristirahatan bagi pengemudi yang berkendara dari jauh seperti mini market. Kekurangan tersebut tidak memenuhi kualitas pelayanan dan kepuasan pelanggan.

Menghindari agar tidak terjadi perbedaan persepsi tentang apa yang diberikan oleh perusahaan dengan apa yang dibutuhkan oleh konsumen itu sendiri memerlukan manajemen untuk mengidentifikasikan apa yang dibutuhkan oleh konsumen secara tepat. Agar SPBU dapat bertahan dan berkembang, pihaknya harus proaktif dan memberikan pelayanan yang berkualitas kepada konsumennya. Dengan cara memahami persepsi konsumen mengenai pelayanan di SPBU maka, SPBU akan mampu bertahan dan unggul dalam persaingan di era globalisasi saat ini. (Edyansyah, 2016). Kesimpulannya manajemen SPBU harus membuka diri untuk menerima perubahan ataupun pergeseran yang menyangkut sudut pandang ataupun menerapkan apa yang diingikan konsumen.

Organisasi bisnis jasa yang mempunyai perhatian besarpada kepuasan pelanggan. Hal itu dikarenakan oleh pelanggan yang mengutamakan kualitas dan juga mengutamakan kecepatan dalam 
pelayanan. Karena SPBU tersebut memiliki banyak kekurangan seperti, pengendara roda dua dan roda empat masih memiliki jalur yang sama sehingga menyebabkan antrian dan pelanggan menunggu terlalu lama, tidak adanya sapaan/senyuman karyawan untuk konsumen saat pengisian bahan bakar dan ucapan terimakasih saat selesai pengisian bahan bakar, tidak terpakainya mhusollah, tidak tersedianya mesin pompa ban dan air radiator bagi konsumen yang memiliki masalah pada ban kendaraannya, tidak adanya Atm center bagi pengemudi yang kekurangan uang, dan tidak tersedianya tempat peristirahatan bagi pengemudi yang berkendara dari jauh seperti mini market.Kekurangan tersebut tidak memenuhi kualitas pelayanan dan kepuasan pelanggan, adapun bukti terdapat pada LAMPIRAN. Semakin besar porsi waktu yang dialokasikan bagi karyawan untuk bekerja, maka membuat waktu tunggu pelanggan menjadi berkurang.

Berdasarkan uraian yang ada diatas maka penulis mengangkat judul Kualitas Pelayanan Stasiun Pengisian Bahan Bakar Umum Panreng Kecamatan Baranti Kabupaten Sidenreng Rappang dengan dengan tujuan untuk mengetahui bagaimana pengaruh kualitas pelayanan pada SPBU Panreng Kecamatan Baranti Kabupaten Sidenreng Rappang dengan tujuan dan untuk mengetahui faktor apa yang paling tinggi pengaruhnya diantara kualitas pelayanan yang meliputi bukti fisik,kehandalan,jaminan, daya tanggap, dan empati terhadap kepuasan pelanggan di SPBU Panreng Kecamatan Baranti Kabupaten Sidenreng Rappang.

Tjiptono (1996) berpendapat bahwa konsep kualitas sering dianggap sebagai ukuran relatifkebaikan suatu produk barang atau jasa yang terdiri atas kualitas desain dan kualitaskesesuaian. Pada kenyataan aspek ini bukanlah satu-satunya aspek kualitas. Kualitas layanan akan memberikan kepuasan total kepada pelanggan, yang untk bisa mencapainya diperlukan strategi, sistem manajemen dan sumber daya manusia. (Samat, 2016).

Menurut Lewis \& Booms dalam Tjiptono \& Chandra (2012 ; 38), kualitas pelayanan sebagai ukurantingkat service yang diberikan mampu sesuai dengan harapan pelanggan.Sedangkan menurut Tjiptono (2010 :29), kualitaspelayanan adalah tingkat kecanggihan service sesuai keinginan pelanggan. (Lestari, 2018). Mempermudah penilaian dan pengukuran kualitas pelayanan dikembangkan suatu alat ukur kualitas layanan yang disebut SERVQUAL (servive quality). SERVQUAL ini merupakan skalamulti item yang dapat digunakan untuk mengukur persepsi pelanggan atas kualitas layanan yang meliputi lima dimensi yaitu :

1. Tangibles (bukti fisik), yaitu besarnya kemampuan satu pihak dalam memberikan service kepada pihak eksternal. Performance dan daya kekuatan dalammemberikan berbagai fasilitas dan bentuknyata dari perusahaan serta kehidupan disekitarnya adalah bukti nyata dari service yang diberikan .

2. Reliability (kehandalan), yaitukemampuan dalam memenuhi kebutuhan yang dijanjikan dengan segera dan memuaskan.

3. Responsiveness (daya tangkap), yaitu kemampuan untuk membantu dan memberikan pelayanan yang cepat (responsif) dan tepat kepada para pelanggan dengan penyampaian informasi yang jelas.

4. Assurance (jaminan), yaitu pengetahuan, keramahtamahan, dan kemampuan memberikan kepercayaan dan keyakinan

5. Empathy (empati), yaitu kepedulian dan pehatian khusus kepadapelanggan/ dapat memahami keinginan dari pelanggan.

Menurut Tjiptono (2013:24) kepuasan atau ketidak puasan pelanggan adalah timbal balik dari responpelanggan terhadap ketidak sesuaian (discinfirmation) yang diberikan antara ekspektasi dan realisasi kinerja yang dirasakan pelanggan. Untuk itu setiap pihak dalam hal ini perusahaan yang memberikan jasa pelayanan sebagai pokok dari tujuan perusahaan. Dengan adanya berbagai saran dan masukan tersebut badan usaha dapat memperbaiki dan meningkatkan layanan sehinggadapat memuaskan konsumen. (Lestari, 2018). Menurut Hawkinz dan Lonney dikutip dalam Tjiptono (2005) dimensi karakteristik kepuasan pelanggan adalah :

1. Kesesuaian harapan, Merupakan tingkat kesesuanin kinerja yang diharapkan oleh pelanggan dengan yang dirasakan oleh pelanggan. 
2. Minat berkunjung kembali Merupakan kesediaan pelanggan untuk berkunjung kembali atau melakukan pembelian ulang terhadap suatu barang.

3. Kesediaan merekomendasikan, Merupakan kesediaan pelanggan merekomendasikan produk yang telah dirasakannya kepada teman atau keluarga. (Imam, 2015)

\section{B. METODE PENELITIAN}

Penelitian ini menggunakan tipe penelitian yang digunakan penulis yaitu kuantitatif dengan jenis penelitian yang deskriptif. Teknik pengumpulan data yang digunakan dalam penelitianini adalah Observasi, Kuesioner, Dokumentasi, dan Studi pustaka. Penulis menggunakan modelregresi sederhana untuk mengetahui hubungan antara variabel independen $(X)$ dengan variabel dependen (Y), dengan formulasinya sebagai berikut :

Dimana:

$$
Y=a+b X+e
$$

$Y=$ Kepuasan Pelanggan
$A=$ Konstanta
$b=$ Koefisien Regresi
$X=$ Kualitas Pelayanan
e = Residual atau Eror
Data yang terkumpul, dianalisa dengan
ata menggunakan skala likert.

\section{HASIL DAN PEMBAHASAN}

Berdasarkan hasil penelitian kualitas pelayanan : a) fasilitas SPBU Panreng sudah lengkap $50 \%$. b) perlengkapan karyawan SPBU Panreng sudah sesuai $59 \%$. c) kemampuan karyawan SPBU Panreng memberikanpelayanan yang sudah sesuai dengan yang dijanjikan 63,8\%. d) berdasarkan data mengenai pelayanan di SPBU Panreng sudah memuaskan 63,4\%. e) ada kesediaan karyawan SPBU Panreng untuk membantu para pelanggan $70 \%$. f) karyawan SPBU Panreng sudah memberikan pelayanan yang cepat dan tepat $67 \%$. g) karyawan SPBU Panreng sudah berperilaku sopan kepada pelanggan $74 \%$. h) karyawan SPBU Panreng memiliki pengetahuan yang luas yang dapat memberikan rasa percaya dan keyakinan 63\%. i) karyawan SPBU Panreng memiliki rasa kepedulian kepada pelanggan $68 \%$. j) karyawan SPBU Panreng sudah memberikan perhatian khusus
p-ISSN 2302-6960

e-ISSN 2716-165X

individual kepada pelanggan 56\%. Dengan mengakumulasikan hasil rata-rata persentase dari 10 pertanyaan pada kualitas pelayanan di atas, maka didapatkan hasil rata-rata persentase yaitu $63,42 \%$.

Berdasarkan hasil penelitian indikator kepuasan pelanggan : a) SPBU Panreng sudah memberikan pelayanan yang baik sesuai dengan harapan para pelanggan $62 \%$. b) SPBU Panreng sudah melakukan pengisian bahanbakar pasti pas sesuai dengan harapan pelanggan $64 \%$. c) berkunjung kembali atau membeli ulang bahan bakar minyak di SPBU Panreng $70 \%$. d) mengenai berkunjung kembali di SPBU Panreng karena memiliki pelayanan yang memuaskan 64\%. e) SPBU Panreng dapat di rekomendasikan (promosikan) sebagai salahsatu SPBU yang memiliki pelayanan yang memuasakan 58\%. f) bahan bakar minyak di SPBU Panreng dapat direkomendasikan (promosikan) kepada teman dan keluarga dikategorikan ragu-ragu dengan jumlah rata-rata persentase $60 \%$. Dengan mengakumulasikan hasil rata-rata persentase dari 6 pertanyaan pada kepuasan pelanggan diatas, maka didapatkan hasil rata-rata persentase yaitu $63 \%$.

Kualitas pelayanan yang dikemukakan oleh Zeithmal $(1990 ; 16)$ Kualitas pelayanan yang pertama itu adalah bukti fisik. Bukti fisik dimana kelengkapan fasilitas SPBU Panreng sebesar $50 \%$, dan perlengkapan karyawan SPBU Panreng sebesar 59\%. Kualitas pelayanan yang kedua itu adalah kehandalan dimana kemampuan karyawan SPBU Panreng memberikan pelayanan sudah sesuai dengan yang dijanjikan sebesar $63,8 \%$ dan pelayanan di SPBU Panreng sudah memuaskan sebesar $63,4 \%$. Kualitas pelayanan yang ketiga itu adalah daya tanggap dimana ada kediaan karyawan SPBU Panreng untuk membantu para pelanggan sebesar $70 \%$ dan karyawan SPBU Panreng sudah memberikan pelayanan yang tepat dan cepat sebesar $67 \%$.

Kualitas pelayanan yang empat itu adalah jaminan dimana karyawan SPBU Panreng sudah berperilaku sopan kepada pelanggan sebesar $74 \%$ dan karyawan SPBU Panreng memiliki pengetahuan yang luas dapat memberikan rasa percaya dan keyakinan sebesar $63 \%$. Kualitas pelayanan yang kelima itu adalah empati. Empati dimana karyawan SPBU Panreng memiliki rasa kepedulian kepada pelanggan sebesar 
$68 \%$ dan karyawan SPBU Panreng sudah memberikan perhatian khusus individual kepada pelanggan sebesar $56 \%$.

Kepuasan pelanggan yang pertama itu adalah kesesuaian harapan. Kesesuaian harapan yangdimaksud disisni yaitu SPBU Panreng sudah memberikan pelayanan yang baik sesuai dengan harapan para pelanggan sebesar $62 \%$ dan melakuakan pengisian bahan bakar pasti pas sesuai dengan harapan pelanggan sebesar $64 \%$. Kepuasan pelanggan yang kedua itu adalah minat berkunjung kembali dimana yang dimaksud disini yaitu berkunjung kembali atau membeli ulang bahan bakar minyak di SPBU Panreng sebesar $70 \%$ dan berkunjung kembali karena memiliki pelayanan yang memuaskan sebesar $64 \%$. Kepuasan pelanggan yang ketiga itu adalah kesediaan merekomendasikan dimana yang dimaksud disini yaitu SPBU Panreng dapat direkomendasikan sebagai salah satu SPBU yang memiliki pelayanan yang memuaskan sebesar $58 \%$ dan bahan bakar minyak SPBU Panreng dapat direkomendasikan kepada teman dan keluarga sebesar $60 \%$.

Hasil dari tabel Model Summary, pada bagian ini ditampilkan nilai $R=0,742$ dan koefisien Determinasi Rsquare atau $\left(R^{2}\right)$ sebesar 0.551 (adalah hasil pengkuadratan dari koefisien korelasi, atau 0,742 $\times 0,742=$ $0,551 \times 100 \%=55,1 \%)$, sedangkan sisanya $(100 \%-55,1 \%=44,9 \%)$. Hal inimenunjukkan pengertian bahwa KualitasPelayanan (X) berpengaruh terhadap Kepuasan Pelanggan (Y) dengan mempunyai hubungan yang lemah karena diperoleh nilai koefisien korelasi sebesar $55,1 \%$.

Hasil dari uji ANOVA pada bagian ini ditampilkan hasil yangdiperoleh adalah nilai $\mathrm{F}$ $=84,733$ dengan tingkat probabilitas sig. 0,000 . Oleh karena probabilitas $(0,000)$ jauh lebih keci dari 0,05, maka model regresi bisa dipakai untuk memprediksi Kualitas Pelayanan. Untuk menguji kebenaran hipotesis dalam penelitian ini dilakukan uji $F$. Untuk mengetahui bahwa pengaruh/Signifikan dapat diketahui dengan melihat dari lefel of signifikan $a=0,05$. Jika nilai signifikan lebihkecil dari 0,05 , maka $\mathrm{HO}$ ditolak dan $\mathrm{Ha}$ diterima. Berdasarkanhasil olah pada tabel ANOVA, maka diketahui nilai Fhitung yang diperoleh sebesar 84,733 dengan tingkat signifikan 0,000 (Sig < 0,05) yang berarti bahwa variabel Kualitas Pelayanan (X) mempunyai pengaruh/signifikan e-ISSN 2716-165X

Pelanggan $(\mathrm{Y})$.

Coefficients hasil olah data, maka modelregresi yang digunakan dalam penelitian ini untuk mengukur kualitaspelayanan terhadap terhadap kepuasan pelanggan di SPBU Panreng.

Dari fungsi regresi di atas, maka dapat dijelaskan :

1. Jika variabel Kualitas Pelayanan (X) berubah, maka Kepuasan Pelanggan ( $Y$ ) juga akan berubah. Tandapositif menunjukkan perubahan yang searah. Apabila Kualitas Pelayanan meningkat, maka Kepuasan Pelanggan juga akan meningkat dengan koefisien regresi sebesar 0,550 dan sebaliknya, jika Kualitas Pelayanan menurun, maka Kepuasan Pelanggan juga akan menurun dengan koefisien regresi sebesar 0,550 .

2. Nilai konstanta sebesar 1,423 menunjukkan bahwa, jika semua variabel konstan maka Kualitas Pelayanan masih bersifat positif.

Uji statistic $t$ untuk menunjukkan seberapa jauh pengaruh satu variabel penjelas/independen secara individuall menerangkan variasi variabel dependen berdasarkan tabel coefficients hasil olah data SPSS, maka diketahui bahwa :

1. Nilai thitung variabel KualitasPelayanan (X) 9,205 dengan tingkat signifikan 0,000.

2. Hipotesis berdasarkan uji $\mathrm{t}$ dirumuskan secara statistic

$\mathrm{Ha}: \mathrm{Pyx} \neq 0$

$\mathrm{HO}:$ Pyx $\neq 0$

1. $\mathrm{Ha}$ : Kualitas Pelayanan berpengaruh/signifikan terhadap Kepuasan Pelanggan di SPBU Panreng .

2. HO : Kualitas Pelayanan tidak berpengaruh/signifikan terhadap Kepuasan Pelanggan di SPBU Panreng

Kaidah Keputusan :

1. Jika nilai $t$ hitung $\geq t$ tabel, maka $\mathrm{HO}$ ditolak dan Ha diterima, artinya Signifikan

2. Jika nilai $t$ hitung $\leq t$ tabel, maka $\mathrm{HO}$ diterima dan $\mathrm{Ha}$ ditolak, artinya tidak Signifikan

Tabel Coefficients diperoleh $\mathrm{t}$ hitung $=$ 9,205 prosedur mencari statistictabel dengan kriteria

1. Tingkat signifikan $(a=0,05)$ 
2. $\mathrm{df}=$ Jumlah Responden -2 atau $71-2=$ 69

$$
\text { 3. } \begin{aligned}
\mathrm{t} \text { tabel } & =\mathrm{a} / 2 ; \mathrm{df} \\
& =0,05 / 2 ; \mathrm{df} \\
& =0,025 ; 69
\end{aligned}
$$

Sehingga $t$ tabel $=1,994$

Ternyata nilai $\mathrm{t}$ hitung $>\mathrm{t}$ tabel atau 9,205 > 1,994, maka $\mathrm{HO}$ ditolak dan $\mathrm{Ha}$ diterima, artinya signifikan. Jadi, Kualitas Pelayanan berpengaruh/signifikan terhadap Kepuasan Pelanggan di SPBU Panreng Kecamatan Baranti Kabupaten Sidenreng Rappang.

\section{KESIMPULAN}

Berdasarkan hasil dan pembahasan yang ada diatas maka hal ini dapat disimpulkan sebagai berikut:

1. Hasil penelitian dan pembahasan nilai keseluruhan untuk pengaruhu kualitas pelayanan terhadap kepuasan pelanggan di SPBU Panreng dengan persentase $55,1 \%$ dinyatakan berpengaruh/signifikan. Hasil dari tabel Model Summary, pada bagian ini ditampilkan nilai $R=0,742$ dan koefisien Determinasi Rsquare atau $\left(R^{2}\right)$ sebesar $0.551 \quad$ (adalah hasil pengkuadratan dari koefisien korelasi, atau $0,742 \times 0,742=0,551 \times 100 \%=$ $55,1 \%)$, sedangkan sisanya $(100 \%$ $55,1 \%=44,9 \%)$. Hal ini menunjukkan pengertian bahwa Kualitas Pelayanan (X) berpengaruh terhadap Kepuasan Pelanggan ( $\mathrm{Y})$ dengan mempunyai hubungan yang lemah karena diperoleh nilai koefisienkorelasi sebesar $55,1 \%$.

2. Hasil penelitian faktor kualitas pelayanan yang meliputi bukti fisik, kehandalan, jaminan, daya tanggap, dan empati yang paling tinggi pengaruhnya terhadap kepuasan pelanggan adalah faktor daya tanggap. Faktor dayatanggap terdiri dari karyawan SPBU Panreng sudah memberikan pelayanan yang tepat dan cepat $67 \%$ dankaryawan SPBU Panreng sudah berperilaku sopan kepada pelanggan $74 \%$. Jadi kualitas pelayanan yang paling tinggi pengaruhnya adalah faktor indikator daya tanggap dengan persentase yang paling tinggi $74 \%$.

\section{E. DAFTAR PUSTAKA}

Ahmad, J. (2015). metode penelitian administrasi publik teori dan aplikasi. (D.

A, Ed.) (cetakan 1). yogyaka: penerbit gava media.
Annisa, W. (2010). Metode penelitian

p-ISSN 2302-6960

e-ISSN 2716-165X

korelasional. (artikel). Dalam Retrieved

from

https://bintangkecilungu.wordpress.com/

2010/10/31/metode-penelitian-

korelasional-2/.di akses tanggal 31

Oktober 2010.

Edyansyah, T. (2016). Analisis Pengaruh Kualitas Pelayanan Terhadap

Kepuasan Pelanggan SPBU Panton Labu Aceh Utara. Visioner \& Strategis, 5(September), 95-105.

Hardiyansyah, D. (2011). kualitas pelayanan publik konsep, dimensi, indikator dan implementasinya. (Rudy, Ed.) (cetakan I,). yogyakarta: gava media.

Imam. (2015). pengaruh kualitas pelayanan terhadap kepuasan konsumen pada rumah makan sop buntut cut meutia di jakarta.

Lestari, F. A. P. (2018). FAKTOR -FAKTOR YANG MEMPENGARUHI KUALITAS PELAYANAN TERHADAP KEPUASAN PELANGGAN. Fibria. SOSIO E-KONS, 10(2), 179-187.

Mugiono, D. B. dan M. S. I. (2010). Analisis pengaruh kualitas pelayanan terhadap kepuasan konsumen (pembeli) di pasar kota malang. WACANA, 13(4), 552-568.

Noorsyamsa Djumara, D. (2009). Standar Pelayanan Publik langkah langkah penyusunan.

Pamungkas, G., \& Barata2, D. D. (2016). Pengaruh Kualitas Pelayanan Terhadap Kepuasan Pelanggan Serta Dampaknya Terhadap Loyalitas pelanggan pasa spbu 34.151.37.Kalbi Socio, 3(1), 4248.

Pratiwi, E. W. (n.d.). Pengaruh Kualitas Pelayanan SPBU Pasti Pas Terhadap Kepuasan Konsumen di Kota Malang (Studi Pada SPBU Pasti Pas Jalan Panglima Sudirman Kota Malang), (0910223068), 1-16.

Samat, Z. (2016). birokrasi dalam pelayanan publik. (D. Qamajaya, Ed.) (cetakan I). yogyaka: ombak.

SARI, N. H. I. P. (2018). ANALISIS 
PENGARUH KUALITAS PELAYANAN

TERHADAP KEPUASAN PELANGGAN DI PT MATAHARI DEPARTMENT STORE SOLO GRAND MALL (STUDI EMPIRIS PADA MASYARAKAT DI WILAYAH SOLO).

Sellang, K. (2019). ADMINISTRASI DAN PELAYANAN PUBLIK Antara Teori dan Aplikasinya. ( dian qamajaya Ridwan, Ed.) (edisi1 ed.). yogyakarta: penerbit ombak.

Servqual, D. (2018). Manajemen Kualitas Jasa. (B. Sarwiji, Ed.) (edisi kedu). Kembangan Utara - jakar tabarat: PT. INDEKS.

Sunyoto, D. (2012). Konsep Dasar Riset Pemasaran \& Perilaku Konsumen. (T. Admojo, Ed.) (pertama). yogyakarta: CAPS.

Suryalena, Y. N. \&. (1997). PENGARUH KUALITAS PELAYANAN TERHADAP KEPUASAN KONSUMEN PADA PT KERETA API INDONESIA (PERSERO) DIVISI REGIONAL II SUMATRA BARAT PADANG PARIAMAN. Oleh. JOM FISIP, 5(1), 1-5.

Tuwu, K. S. L., \& Basri, M. (2019). PENERAPAN PELAYANAN PRINSIP-PRINSIP DALAM PELAYANAN KARTU TANDA PENDUDUK ELEKTRONIK PADA KABUPATEN SIDENRENG RAPPANG, (January), 608-615.

Undang-Undang Republik Indonesia Nomor 25 Tahun 2009 Tentang Pelayanan Publik. (2009). 